\title{
Coulisses
}

Revue de théâtre

2 | Automne 1990

Spécial Festival des idées : Besançon ville ouverte aux jeunes

\section{Rock au CLA}

\section{Rédaction}

\section{(2) OpenEdition}

\section{Journals}

\section{Édition électronique}

URL : http://journals.openedition.org/coulisses/1583

DOI : $10.4000 /$ coulisses. 1583

ISSN : 2546-9460

Éditeur

Presses universitaires de Franche-Comté

\section{Édition imprimée}

Date de publication : 1 novembre 1990

Pagination : $\mathrm{np}$

ISSN : 1150-594X

\section{Référence électronique}

Rédaction, «Rock au CLA », Coulisses [En ligne], 2 | Automne 1990, mis en ligne le 04 juillet 2017, consulté le 24 octobre 2019. URL : http://journals.openedition.org/coulisses/1583 ; DOI : 10.4000/ coulisses. 1583

Ce document a été généré automatiquement le 24 octobre 2019.

Coulisses 


\section{Rock au CLA}

\section{Rédaction}

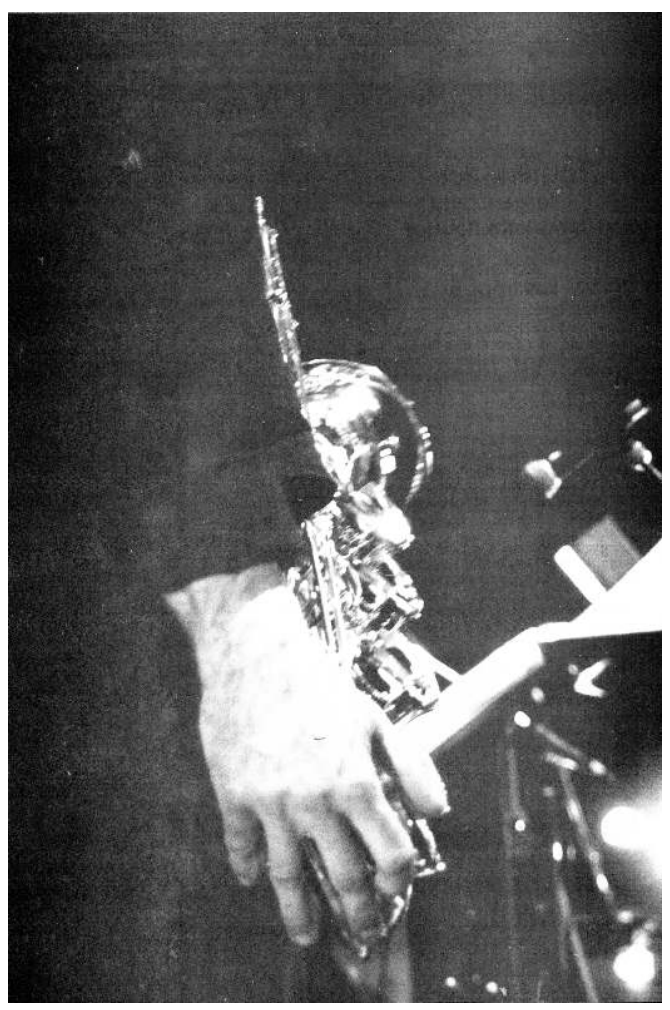

(c) Collectif Photo BVOJ 90.

\section{Import-export}

Ce groupe de quatre musiciens a trouvé la manière de transformer l'atmosphère habituelle de la «cave » du CLA en une ambiance chaude et humide que l'on pourrait imaginer dans les Underground anglais ou américains. La musique «blues-rock» témoigne de la maturité de ces musiciens de Dijon. L'accent ricain du chanteur, le 
feeling de leurs mélodies, les prestations improvisées à l'harmonica nous ont plongés dans un monde qu'il nous a été difficile de quitter.

\section{Les escargots teigneux}

2 Décidément, le nombre quatre est un leitmotiv dans les groupes de rock. Pourtant les Escargots teigneux ont su marquer la différence. Même si la moyenne d'âge du groupe est de 37 ans, ils nous ont montré qu'ils avaient quelque chose « sous la coquille ». Leur concert - le premier - était selon le chanteur un défi. Contre qui, contre quoi? Mystère! Les reprises des Naufragés ou de Dutronc n'étaient pas de simples calques. Même si le groupe n'existe que depuis trois mois, il donne aux morceaux, l'esprit des Escargots teigneux. Leurs spectateurs - qui se sont éclipsés lorsque Susan and the Visitors leur ont succédé - paraissaient satisfaits de la première sortie de ces quatre gastéropodes.

\section{Susan and the Visitors}

Ce nom visite depuis quatre ans les scènes de concerts de Besançon. Sélectionnés dans le cadre des «Découvertes » du Printemps de Bourges en 89, les quatre musiciens ont réussi à décrocher des contrats dans la France entière. Leurs mélodies « rock-ricaines ", dont les paroles et la musique sont écrites par la chanteuse et arrangées par le guitariste seraient peut-être un peu fades sans le son folk- irlandais du violon.

4 Quelques morceaux connaissent un peu de longueurs et de répétitions, mais d'une manière générale, le public paraissait se donner sans trop de difficultés au rythme des musiciens, dominé - et c'est ce qui fait peut-être leur originalité - par les ballades du violon. 